UDC 615.4:339:661.158:636.085/.087:543.253

\author{
O. Y. STRus ${ }^{1}$, N. P. Polovko ${ }^{2}$, K. I. SMETANina ${ }^{1}$ \\ ${ }^{1}$ Danylo Halytsky Lviv National Medical University \\ ${ }^{2}$ National University of Pharmacy
}

\title{
MARKETING ASPECTS OF THE DEVELOPMENT OF VETERINARY PREPARATIONS BASED ON PELOIDS AND PRODUCTS OF THEIR PROCESSING
}

The use of peloids and their derivatives in veterinary is based on their low toxicity and a wide range of the pharmacological activity due to the multi-component chemical composition and significant resources of this raw material in Ukraine.

Aim. To monitor the range of veterinary preparations based on peloids and products of their processing used in veterinary medicine at the Ukrainian market for further substantiation of the feasibility of developing domestic drugs based on peloids.

Materials and methods. The study used marketing and statistical methods for analyzing electronic sources of information and scientific publications. The study objects were the information about veterinary preparations developed from pelloids and products of their processing and registered in Ukraine. The catalogs of veterinary drugs, feed supplements, premixes registered in Ukraine, the Russian Federation, the Republic of Belarus, instructions for their use, electronic catalogs, etc., were studied in depth.

The theoretical side of the research was based on scientific publications of domestic and foreign scientists. The empirical base was focused on the analysis of information set forth in the State Register of Medicinal Products of Ukraine, electronic databases using the information retrieval program "Morion", the price lists of "Apteka" weekly as of 2018. The logical, system-analytical, structural-functional and comparative methods of analysis were used in the article.

Monitoring of the range of products from peloids taking into account the ATC classification system has shown that the pharmaceutical market is represented by drugs belonging to the following groups: $\mathrm{M} 02 \mathrm{AH}$ - other drugs used topically for joint and muscle pain, C05BA - heparin and heparinoids for topical use and C05CX - other capillary-stabilizing drugs.

Results. The analysis of the range of preparations of peloids and their derivatives used in veterinary medicine has shown that most of them are presented by premixes and feed supplements (75\%), veterinary preparations $(21 \%)$ and preservatives $(4 \%)$. The basis of the Ukrainian pharmaceutical market is the products of the Russian Federation, Ukraine, Belarus, Germany, and Hungary.

Conclusions. The absence of veterinary preparations based on sapropels at the Ukrainian market, a poor range of feed supplements indicates the need and relevance of the development of veterinary products sapropel derivatives.

Key words: peloids; sapropel; veterinary preparations; feed supplements; premixes; marketing research.

О. Є. Струс ${ }^{1}$, Н. П. Половко ${ }^{2}$, К. І. СметАнінА ${ }^{1}$

1 Львівський національний медичний університет імені Данила Галищького

${ }^{2}$ Національний фармащевтичний університет

МАРКЕТИНГОВІ АСПЕКТИ РОЗРОБКИ ВЕТЕРИНАРНИХ ПРЕПАРАТІВ НА ОСНОВІ ПЕЛОЇДІВ I ПРОДУКТІВ ЇХ ПЕРЕРОБКИ

Використання пелоїдів та їх похідних у ветеринарії пов'язано з низькою токсичністю та широким спектром фармакологічної активності, що зумовлено полікомпонентним хімічним складом та значними ресурсами цієї сировини в Україні.

Мета: моніторинг асортименту ветеринарних препаратів на основі пелоїдів та продуктів їх переробки, які використовуються у ветеринарії, на українському ринку для подальшого обгрунтування доцільності розробки вітчизняних препаратів на основі пелоїдів.

Матеріали та методи: маркетингові та статистичні методи дослідження електронних джерел інформації та низка наукових публікацій. Об’єктом досліджень була інформація про наявні в Україні ветеринарні препарати на основі пелоїдів. Вивчали каталоги зареєстрованих в Україні, РФ, Республіці Білорусь ветеринарних препаратів, кормових добавок, преміксів; інструкції для застосування, електронні каталоги тощо. Теоретичну основу дослідження складали наукові праці вітчизняних та закордонних учених. Аналіз проводився на основі даних Державного реєстру лікарських засобів України, електронних баз даних, інформаційно-пошукової програми «Моріон» та прайс-листів щотижневика «Аптека» станом на 2018 р., що складали емпіричну базу дослідження. Були використані логічний, системно-аналітичний, структурно-функціональний та порівняльний методи аналізу. Моніторинг асортименту препаратів проводився згідно з Державним реєстром лікарських засобів України і класифікаційної системи АТС. Нами було досліджено фармацевтичний ринок лікарських препаратів, установлено, що препарати пелоїдів належать до груп M02AX - Інші засоби, що застосовуються місцево при суглобовому та м'язовому болю, С05ВА - Гепарин або гепариноїди для місцевого застосування та С05CX - Інші капіляростабілізувальні засоби. 
Результати дослідження. Аналіз асортименту препаратів на основі пелоїдів, які використовуються у ветеринарії, показав, що переважна більшість це премікси і кормові добавки (75 \%), ветеринарні препарати складають $21 \%$, а консерванти - 4 \%. На ринку України продукція з пелоїдів представлена російськими, білоруськими, німецькими, угорськими та українськими виробниками.

Висновки. Відсутність на ринку України ветеринарних препаратів на основі сапропелів, а також невеликий асортимент кормових добавок свідчать про актуальність розробки таких ветеринарних засобів.

Ключові слова: пелоїди; сапропель; ветеринарні засоби; кормові добавки; премікси; маркетингові дослідження

\section{О. Е. Струс ${ }^{1}$ Н. П. Половко ${ }^{2}$, Е. И. СмЕтАнинА}

${ }^{1}$ Национальный фармацевтический университет

2 Львовский национальный медицинскй университет имени Данила Галицкого

\section{МАРКЕТИНГОВЫЕ АСПЕКТЫ РАЗРАБОТКИ ВЕТЕРИНАРНЫХ ПРЕПАРАТОВ НА ОСНОВЕ} ПЕЛОИДОВ И ПРОДУКТОВ ИХ ПЕРЕРАБОТКИ

Использование препаратов пелоидов в ветеринарии основывается на их низкой токсичности и широком спектре фармакологической активности, что обусловлено поликомпонентным химическим составом и значительными ресурсами этого сырья в Украине.

Цель: мониторинг ассортимента ветеринарных препаратов на основе пелоидов и продуктов их переработки, используемых в ветеринарии, на украинском рынке для дальнейшего обоснования целесообразности разработки отечественных препаратов на основе пелоидов.

Материалы и методы: маркетинговые и статистические методы анализа электронных источников информации и научных публикаций. Объектом исследований была информация о зарегистрированных в Украине ветеринарных препаратах, разработанных из пелоидов и продуктов их переработки. Углубленно изучались каталоги украинских, российских, белорусских производителей ветеринарных препаратов, кормовых добавок, премиксов; инструкции по их использованию, электронные и научные материалы. Теоретическую основу исследования составляли научные публикации отечественных и зарубежных ученых. Эмпирическая база фокусировалась на анализе информации Государственного реестра лекарственных средств Украины, электронных баз данных с использованием информационно-поисковой программы «Морион», прайс-листов еженедельника «Аптека» по состоянию на 2018 г. В публикации использовали логический, системно-аналитический, структурно-функциональный и сравнительный методы анализа. Мониторинг ассортимента продукции из пелоидов с учетом классификационной системы АТС показал, что фармацевтический рынок представлен группами M02AX - Другие средства, которые используются местно при суставной и мышечной боли; C05BA - Гепарин и гепариноиды для местного применения и С05CX - Другие капилляростабилизирующие средства.

Результаты исследования. Анализ ассортимента препаратов пелоидов и их производных, используемых в ветеринарии, показал, что большинство из них представлены премиксами и кормовыми добавками (75 \%), ветеринарными препаратами (21\%) и консервантами (4 \%). На украинском фармацевтическом рынке представлена продукция РФ, Украины, Беларуси, Германии, Венгрии.

Выводы. Отсутствие на рынке Украины ветеринарных препаратов на основе сапропелей, скудный ассортимент кормовых добавок свидетельствуют о необходимости и актуальности разработки таких ветеринарных средств.

Ключевые слова: пелоиды; сапропель; ветеринарные препараты; кормовые добавки; премиксы; маркетинговые исследования.

Statement of the problem. The use of peloids and their derivatives in veterinary is based on their low toxicity and a wide range of the pharmacological activity due to the multicomponent chemical composition (amino acids (AA), organic acids (OA), vitamins, macroand microelements, humic acids (HA), as well as significant resources of this raw material in Ukraine.

At the present stage, the market of sapropel preparations is represented by feed supplements (FS) and new generation premixes natural sapropels $[1,2]$. Each preparation is characterized by its chemical composition, which is formed under the influence of a number of environmental factors, formation conditions, differences in composition, etc. [3].

Unfortunately, feeding natural sapropels are mainly exported to our market from neighboring countries, such as Russia, Belarus [2]. Western companies do not use peloids for production of FS and premixes due to poor knowledge or the lack of the raw material $[4,5]$. And in Ukraine, work on the FS production increased only in the last decade [6-8].

Veterinary preparations (VP) as a component of the medicinal mud preparation market constitute about $1 / 3$ of all products [9], and the study of their therapeutic properties is a promising direction of modern veterinary medicine [10-14]. 
As is well known, according to the requirements of the European legislation any medicine is obliged to undergo a series of stages for implementation of it in practice. The main factors are standardization and certification [15]. They are quite complex and laborious processes that affect the quality of a medicine in the future and the conditions of its use. FS, premixes, peloid processing products or peloid derivatives (PD) used in veterinary medicine have a simplified standardization system applied to supplements and their analogs [16]. This is mainly due to the active presence of such products at the pharmaceutical market.

In veterinary medicine mud preparations and combination compounds have a number of advantages and are used as enterosorbents; immunomodulators; animal growth (productivity) stimulants; medicines with the antimicrobial, wound healing, anticancer effects; for the treatment and prevention of iron deficiency anemia; adaptogenes and others [12, 17-19].

The marketing analysis of the PD market in Ukraine [20] has shown that mainly VP are represented by products based on peat and its derivatives, FS - sapropels, peat and PD. In connection with the expansion of the range of feed additives, veterinary preparations and peloid premixes (therapeutic mud, sapropels), it is necessary to systematize the latter, if possible, to classify them and show their importance and relevance at the present stage.

Analysis of recent research and publications. Our analysis of publications and electronic information sources showed that the Department of General, Inorganic and Bioorganic Chemistry of the Samara State Medical University, the Tula State University, the Siberian State University, the Pacific Institute of Bioorganic Chemistry (Russia), the Institute of Animal Husbandry of the National Academy of Sciences of Belarus and others are engaged in studying the chemical composition, properties and the biological activity of medicinal muds. The National Research Tomsk State University (Russia) studied the issues of the rational use and processing of sapropel.

In Ukraine, the biogeochemical composition of sapropel silts (deposits) for use in crop production to increase crop yields is studied by the I. Franko Lviv National University; the Department of Marine Geology and Sedimentary
Ore-Formation of the NAS of Ukraine concerns the issues of studying the composition, methods of extraction, the possibilities of using sapropels, as well as information about the reserves of this raw material in Ukraine.

Thus, the works of N. P. Avvakumova with co-authors are devoted to the study of the peloid composition features that affect their quality and practical application [3]; the comparative analysis of thermodynamic properties of peloids [21]; the study of therapeutic properties [22]. G. D. Ryzhova developed the optimal method for sapropel processing by physicochemical methods [23]. V. V. Platonov studied the biological effect of sapropel and medicines on their basis $[12,24]$. S. V. Muradov conducted the study of the microbiological activity and biomedical testing of therapeutic mud preparations [11]. Kh. G. Karagulov developed cosmeceuticals of peloids [4]. Domestic scientists studied natural deposits of sapropels and their properties (M. Y. Shevchuk, 1996; S. M. Shtin, 2005; V. O. Khmelivsky, 2017) [7, 8, 25], therapeutic properties and prospects of creating new medicines on their basis (N. S. Fizor, 2012; O. E. Strus, 2014) $[13,14]$ and others.

Separately, the State Register of Medicinal Products of Ukraine [26], the National Drug Formulary [27], and Anatomical Therapeutic Chemical (ATC) classification system [28] were analyzed. The study of the Ukrainian pharmaceutical market of medicines was conducted, and it was found that peloid preparations were represented by the following groups: M02AXM other drugs used topically for joint and muscle pain, C05BA - heparin and heparinoids for topical use and C05CX - other capillary-stabilizing drugs.

Identification of aspects of the problem unsolved previously. Unfortunately, in Ukraine, which has sapropel reserves of more than 86 million tons, its extraction, use and processing are at a low level, and the research work is practically is not carried out. Extraction and processing of sapropel in the territory of Ukraine are done by several enterprises: "Volynsaprofos", "Zender Ukraine" (Volyn region) and "Sapropel Center" (Kyiv region). The economic effect of their use in various fields has already been proven by the experience of our neighbors.

Thus, according to the Republican Unitary Enterprise (RUE) of the Institute of Animal 
Husbandry of the National Academy of Sciences of Belarus, the use of a ton of a dry sapropel gives an economic effect of 70 EUR $[4,5,25]$. Therefore, the analysis of economic indicators when using peloids not only in agriculture, extraction, but also in the pharmaceutical and veterinary fields, which may be the subject of further research, should be considered promising.

The topical issue of our time is ecological situation. Cleaning lakes from sapropels simultaneously solves the problem of their preservation. Extraction of sapropel leads to deepening of lake basins, and therefore, improves the hydrological, hydrochemical and biological regime of lakes and has a positive effect on the environment [4, 19, 25]. Environmental safety issues have always deserved a careful study not only by science, but also the public.

As is known, peloids and PD are widely used in veterinary medicine. However, there is practically no systematization of such preparations, and in fact, the composition has not been analyzed. There are several sapropel classifications, and the most common ones are the classification based on the chemical composition and the method of obtaining (mechanical and chemical) $[4,9,10]$. The issues of the classification of mud extraction preparations are not sufficiently studied and do not have an unambiguous interpretation; it is due to their complex composition and the variety of methods for obtaining. Thus, work in these areas is quite relevant at the present stage.

Objective statement of the article. Based on the foregoing, monitoring of the marketing research of FS, VP and PD market is an important task of the modern stage of veterinary medicine development in the context of industry reform, and therefore, is the aim of our publication.

Presentation of the main material of the research. The information on VP from peloids that were popular in Ukraine was collected; the screening of catalogs of VP, FS, premixes registered in Ukraine, Russia, Republic of Belarus, their instructions for use was conducted using marketing and statistical methods of analysis of scientific materials and electronic databases using the information retrieval program "Morion", the materials of "Apteka" weekly as of 2018.

The range of mud products present at the Ukrainian market was systematized, with a focus on the manufacturer, drug form, the drug composition. The results of the analysis are given in Table.

Table

MODERN PELOID PREPARATIONS (PP) AND THEIR DERIVATIVES (PD)

\begin{tabular}{|c|c|c|}
\hline Name of PP or PD & Drug forms & Composition \\
\hline 1 & 2 & 3 \\
\hline \multicolumn{3}{|c|}{ Feed supplements (FS) } \\
\hline \multicolumn{3}{|c|}{$\begin{array}{l}\text { Institute for Nature Management of the National Academy of Sciences of Belarus, } \\
\text { JSC “Lelchitsky Agroservice", Republic of Belarus [1] }\end{array}$} \\
\hline $\begin{array}{l}\text { 1. Sapropel for feed supplements, } \\
\text { sapropel of the Pribilovichi lake }\end{array}$ & $\begin{array}{l}\text { a dry granular powder from } \\
\text { gray to dark brown color }\end{array}$ & $\mathrm{HA}$ \\
\hline $\begin{array}{l}\text { 2. Organic sapropel for feed, sapropel of } \\
\text { the Pribilovichi lake }\end{array}$ & $\begin{array}{l}\text { a granular powder from } \\
\text { gray to dark brown color }\end{array}$ & $\mathrm{HA}$ \\
\hline $\begin{array}{l}\text { 3. A protein-vitamin-mineral concentrate } \\
\text { based on sapropel of the Pribilovichi lake }\end{array}$ & $\begin{array}{l}\text { a dry granular powder from } \\
\text { gray to dark brown color }\end{array}$ & $\mathrm{HA}$ \\
\hline $\begin{array}{l}\text { 4. Sapropel FS, sapropel of the } \\
\text { Pribilovichi lake }\end{array}$ & granules or powder & $\mathrm{HA}$ \\
\hline $\begin{array}{l}\text { 5. Humosil, biologically active FS } \\
\text { enriched with selenium }\end{array}$ & granules or powder & $\begin{array}{l}\text { humic substances and melanoi- } \\
\text { dins }(65-70 \%) \text {, carboxylic acids } \\
(15-20 \%), \text { AA }(2-4 \%) \text {, pectins } \\
(6-7 \%) \text {, selenium }(0.5-0.7 \mathrm{mg} / \\
\mathrm{kg}) \text {, iodine }(10.5-11.5 \mathrm{mg} / \mathrm{kg})\end{array}$ \\
\hline $\begin{array}{l}\text { 6. Humoplus - a preservative of wet flat- } \\
\text { tened grain, sapropel of the Pribilovichi } \\
\text { lake }\end{array}$ & $\begin{array}{l}\text { granules or powder ob- } \\
\text { tained on the basis of peat } \\
\text { oxidation products and } \\
\text { carbimide }\end{array}$ & HA, phenolcarboxylic acids \\
\hline
\end{tabular}


Continuation of Table

\begin{tabular}{|c|c|c|}
\hline 1 & 2 & 3 \\
\hline \multicolumn{3}{|c|}{ CJSC “Respect” (LLC“Vega-2000 - SO”, Omsk, Russia) [29, 30] } \\
\hline $\begin{array}{l}\text { 7. SaproSORB-FS, sorbent / adsorbent, } \\
\text { lakes of the Omsk region }\end{array}$ & granules & $\begin{array}{l}\text { AA: lysine, methio-nine, threo- } \\
\text { nine, fat, iodine, sulfur, man- } \\
\text { ganese, ash, nitrogen, calcium, } \\
\text { potassium, phosphorus, crude } \\
\text { protein, iron, magne-sium, zinc, } \\
\text { copper, sodium, vitamin A, B2, } \\
\text { B4, B12, C, D, E, heat treated } \\
\text { sapropel }\end{array}$ \\
\hline \multicolumn{3}{|c|}{ Organic premixes based on SaproSORB } \\
\hline $\begin{array}{l}\text { 8.Premix for growing, fattening pigs, } \\
\text { cows, laying hens, broilers }\end{array}$ & granules & $\begin{array}{l}\text { Sapropel enriched with } \\
\text { vitamins and microelements }\end{array}$ \\
\hline $\begin{array}{l}\text { 9. Extract of sapropel from lakes in the } \\
\text { Omsk region }\end{array}$ & $\begin{array}{l}\text { solution for indoor and } \\
\text { outdoor use }\end{array}$ & $\begin{array}{l}\text { tar-like and ichthyol-like sub- } \\
\text { stances, hormone-like sub- } \\
\text { stances and peptides, enzymes; } \\
\text { antioxidants; vitamins E, B12 }\end{array}$ \\
\hline \multicolumn{3}{|c|}{ Agropremix, "Capital-PROK”, Moscow, Russian Federation [31, 32] } \\
\hline 10. Premix-Milk & powder & $\begin{array}{l}\text { macro- and micro-elements, vi- } \\
\text { tamins } \mathrm{A}, \mathrm{D}_{3}, \mathrm{E} \text {, niacin, L-lysine, } \\
\text { sapropel, humic additive, pro- } \\
\text { biotic Lactobacillus acidophilus, } \\
\text { Ruminococus alus }\end{array}$ \\
\hline $\begin{array}{l}\text { 11. Premixes -"A storehouse of } 34 \\
\text { formulas" concentrates }\end{array}$ & powder & $\begin{array}{l}\text { calcium phosphate, natural zeo- } \\
\text { lites, sapropel, limestone, chalk, } \\
\text { wheat flour, wheat bran, vita- } \\
\text { mins, micro, macronut-rients, } \\
\text { AA, antio-xidants, antimicrobial } \\
\text { and enzymatic substances }\end{array}$ \\
\hline 12. Gumival, FS & powder & $\begin{array}{l}\text { product of natural or artificial } \\
\text { lignin meta-bolism to humic } \\
\text { substances }\end{array}$ \\
\hline \multicolumn{3}{|c|}{ “Ekorost" LLC (Ryazan Region, Russian Federation) [2] } \\
\hline 13. "Ekorost" - humic FS & water suspension & $\begin{array}{l}\text { suspension of humic and fulvic } \\
\text { acids obtained by alkaline } \\
\text { extraction from peat }\end{array}$ \\
\hline \multicolumn{3}{|c|}{ EXPERT-MEDICAL LTD., Hungary [2] } \\
\hline 14. Humapol & water suspension & peat suspension cotaining $\mathrm{HA}$ \\
\hline \multicolumn{3}{|c|}{ Humentech GmbH, Germany [2] } \\
\hline 15. Huminfide & granulated powder & $\begin{array}{l}\text { sodium humate, sodium oxide } \\
(12-13 \%)\end{array}$ \\
\hline \multicolumn{3}{|c|}{ "Freya", Cherkasy region, Gorodishche, Ukraine [33] } \\
\hline 16. Humate sodium FS “Freya” & powder & sodium humate \\
\hline \multicolumn{3}{|c|}{ "Agrofirma Hermes" Ltd, Ukraine [1] } \\
\hline 17. Humisol - T2 & solution & $\begin{array}{l}\text { HA and their salts, lactic } \\
\text { bacteria, bifidus bacteria, } \\
\text { Bacillus subtilis }\end{array}$ \\
\hline \multicolumn{3}{|c|}{ Veterinary preparations } \\
\hline $\begin{array}{l}\text { 1. Enterosorbent EST-1 (Rese-arch Insti- } \\
\text { tute of Agrarian Problems of Khakassia, } \\
\text { Siberian Branch of the Russian Academy } \\
\text { of Medical Sciences and the Siberian Re- } \\
\text { search Institute of Peat, Russian Academy } \\
\text { of Medical Sciences, Tomsk, Russia) }\end{array}$ & $\begin{array}{l}\text { light-brown powder with } \\
\text { an astringent taste }\end{array}$ & $\begin{array}{l}\text { complex of vitamins, mineral } \\
\text { and humic substances, probiot- } \\
\text { ics Lacto bacillus acidophilus, } \\
\text { Ruminococcus albus }\end{array}$ \\
\hline
\end{tabular}


Continuation of Table

\begin{tabular}{|l|l|l|}
\hline \multicolumn{1}{|c|}{1} & \multicolumn{1}{|c|}{2} & \multicolumn{1}{|c|}{3} \\
\hline $\begin{array}{l}\text { 2 Guvitan-C ("Ariadne", Ekaterinburg, } \\
\text { Russia) }\end{array}$ & vegetable solution & $\begin{array}{l}\text { sodium salts of HA, fulvic acids, } \\
\text { AA peptides, polysac-charides, } \\
\text { calcium, phosphorus, enzymes }\end{array}$ \\
\hline $\begin{array}{l}\text { 3. Ligfol (All-Russian Research Institute of } \\
\text { Pathology, Pharmacology and Therapy } \\
\text { together with LLC "Ligfarm", RF) }\end{array}$ & $\begin{array}{l}\text { injection; dark brown } \\
\text { liquid; glass bottles of 1, 5, } \\
10,50,100,250 \text { ml }\end{array}$ & $\begin{array}{l}\text { GH-butanol fraction from } \\
5.6 \text { mg to 6.9 mg; excipients: } \\
\text { sodium diphosphate, sodium } \\
\text { chloride, water for injection }\end{array}$ \\
\hline $\begin{array}{l}\text { 4. Ferrostim (North-Caucasian Zonal } \\
\text { NI-VI, Novocherkassk, Russia) }\end{array}$ & $\begin{array}{l}\text { powder, peat proces-sing } \\
\text { product }\end{array}$ & $\begin{array}{l}\text { amino, humic and fulvic acids, } \\
\text { iron }\end{array}$ \\
\hline $\begin{array}{l}\text { 5. Humadap (SIGUM CJSC, Russia) } \\
\text { peat processing solution }\end{array}$ & $\begin{array}{l}\text { conc. solution of bioactive } \\
\text { humic compounds }\end{array}$ \\
\hline $\begin{array}{l}\text { 6 Humiton (SSI Siberian Research } \\
\text { Institute of Agriculture and Peat, Siberian } \\
\text { Branch of the Agricultural Academy, } \\
\text { Tomsk, Russia) }\end{array}$ & peat processing solution & $\begin{array}{l}\text { HA and fulvic acids; carboxylic } \\
\text { acids, 16 AA, up to 40 macro- and } \\
\text { microelements, vitamin B, A, E, } \\
\text { salts of OA, alcohols, phenols }\end{array}$ \\
\hline $\begin{array}{l}\text { 7. Liquid extract of sapropel ES-2 (LLC } \\
\text { "Vega-2000 - CO", Omsk region, Omsk, } \\
\text { Russia) }\end{array}$ & $\begin{array}{l}\text { solution obtained by } \\
\text { extraction from sapropel }\end{array}$ & $\begin{array}{l}\text { conc. solution of bioactive } \\
\text { humic compounds }\end{array}$ \\
\hline
\end{tabular}

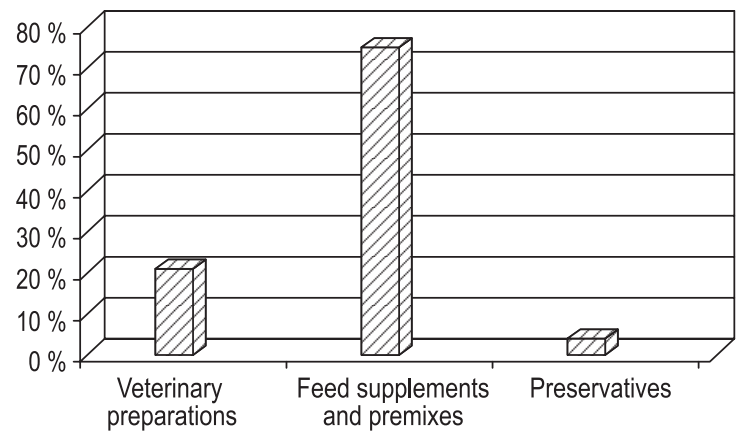

Fig. 1. Distribution of preparations based on peloid derivatives by their indications

As can be seen from Table, most FS and premixes are produced on the basis of sapropel with the main active ingredient - humic substances, and they all have differences in the chemical composition.

The entire range of PP and PD was distributed according to their purpose (Fig. 1). It has been determined that the overwhelming majority

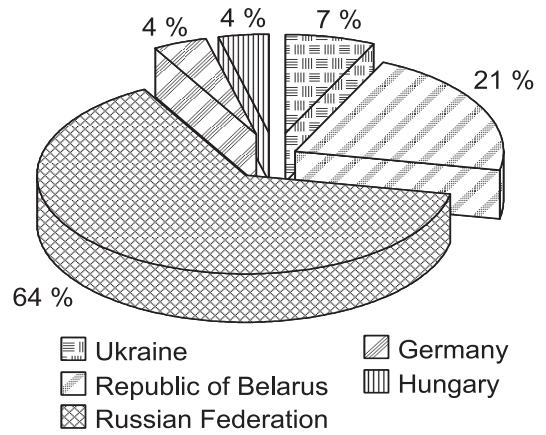

Fig. 2. Distribution of peloid-based products by manufacturer countries

(75\%) are premixes and feed supplements; veterinary preparations accounts for $21 \%$ of the available range; $4 \%$ are preservatives.

In the course of the study it has been found that VP are mainly represented by manufacturers of the Russian Federation. At the same time, FS and premixes are produced by different countries (Fig. 2).

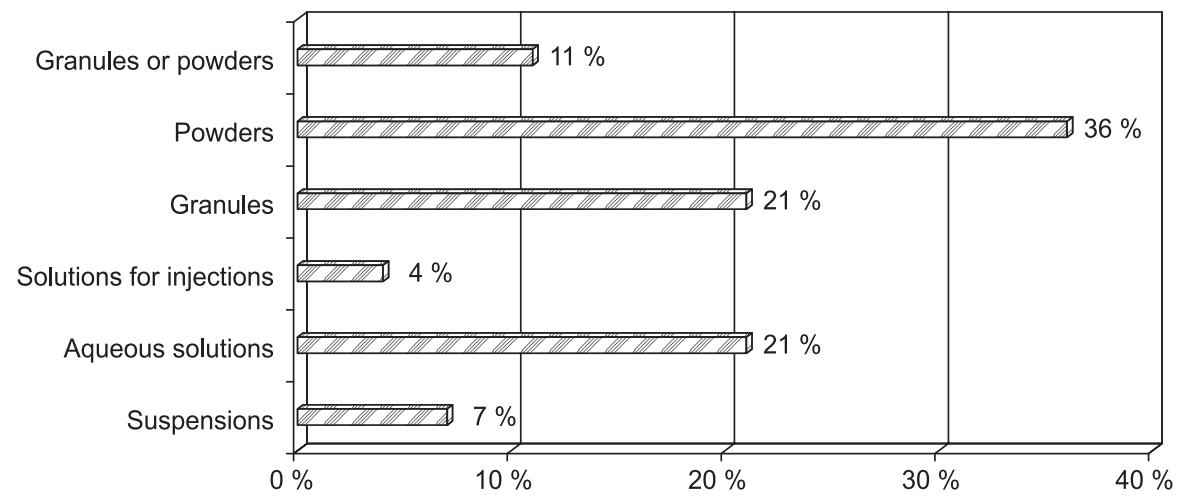

Fig. 3. Distribution of peloid-based products by the drug form 
Moreover, the share of the Russian manufacturer accounts for $64 \%$, and the Ukrainian producer has only $7 \%$ of the drugs analyzed.

The analysis of preparations according to the drug forms has shown that powders prevail - $36 \%$, granules and solutions - $21 \%$, granules or powders $-11 \%$, suspensions - $7 \%$ of all medicines. Only one preparation is produced in the form of solution for injections, and it is $4 \%$ ("Ligfol", Russia) (Fig. 3).

Conclusions. The analysis of the range of derivatives of peloids used in veterinary medicine has shown that the overwhelming majority of preparations are presented by premixes and feed supplements. The domestic market of peloid drugs is, in fact, import-dependent.

Due to the low level of financing of the industry the Ukrainian manufacturer develops and produces only FS, it is conditioned by the relative simplified registration scheme of the latter when bringing them to a competitive market.

Prospects for further research. The absence of veterinary preparations based on sapropels at the Ukrainian market, and a poor range of feed supplements indicate the relevance of the development of new veterinary products.

Conflict of interests: authors have no conflict of interests to declare.

\section{References}

1. Добавки кормовые: Сапропель для кормовых добавок [Электронный ресурс]. - Режим доступа: http://gskp.by/DetailProd.php?UrlReg=0\&UrlDist= 0\&UrlGoodsId=42525\&UrlKlpId=3798 4\&UrlGoodsAssrId=80714\&TabId=3 (дата обращения: 04.07.2017).

2. Список зарегистрированных кормовых добавок [Электронный ресурс]. - Режим доступа: https://galen.vetrf.ru/\#/registry/feed/registry?page=1 (дата обращения: 29.06.2017).

3. Некоторые особенности функционально-группового состава гумусовых кислот пелоидов / Н. П. Аввакумова, М. А. Кривопалова, И. В. Фомин, А. В. Жданова // Вопросы биологической, медицинской и фармацевтической химии. - 2010. - № 11. - С. 24-27.

4. Карагулов, Х. Г. Создание и методология лекарственных и космецевтических средств, содержащих тамбуканские пелоиды, на основе современных ресурсосберегающих технологий: дис. ... докт. фарм. наук: 14.04.01 / Х. Г. Карагулов. - Пятигорск, 2016. - 320 с. - Режим доступа: http://www.dslib.net/klinika-farmakologia/sozdanie-i-metodologija-lekarstvennyh-ikosmecevticheskih-sredstv-soderzhawih.html (дата обращения: 12.02.2019).

5. Механико-физическая технология переработки природного органического сырья и получение продуктов функционального назначения [Электронный ресурс] / Г. Л. Рыжова, К. А. Дычко, В. В. Хасанов, С. А. Богачев, Т. Т. Куряева. - Режим доступа: https://cyberleninka.ru/article/n/ mehano-fizicheskaya-tehnologiya-pererabotki-prirodnogo-organicheskogo-syrya-i-poluchenieproduktov-funktsionalnogo-naznacheniya (дата обращения: 12.02.2019).

6. Донні відклади природних водойм Волинської області та перспективи їх використання у рекреації [Електронный ресурс]. - Режим доступу: http://dspace.nbuv.gov.ua/bitstream/ handle/123456789/35497/37-Kalinovskiy.pdf? sequence=1 (дата звернення: 12.02.2019).

7. Шевчук, М. Й. Сучасний стан озера Прибич та заходи для відновлення його гідрологічної ролі / М. Й. Шевчук, Т. П. Дідковська, А. М. Бортнік // Науковий вісник Волинського національного університету імені Лесі Українки. Географічні науки. - 2009. - Вип. 1. - С. 83-85.

8. Хмелівський, В. О. Сапропелеві мули озер Шацького національного природного парку [Електронний ресурс] / В. О. Хмелівський, В. І. Баранов, О. В. Костюк // Заповідна справа в Україні. - 2011. - Т. 11, вип. 1-2. - Режим доступу: http://aetos.kiev.ua/zsu/zsu17/zsu17-16.pdf (дата звернення: 12.02.2019).

9. Полный каталог зарегистрированных в Украине ветеринарных препаратов VET.in.UA [Электронный ресурс] // Ветеринарный информационный ресурс. - Режим доступа: http://vet. in.ua/menu/drugs.php (дата обращения: 29.06.2017).

10. Карагулов, Х. Г. Современные подходы к получению препаратов лечебных грязей (пелоидов) : обзор литературы // Актуальные проблемы гуманитарных и естественных наук. - 2015. № 4-2. - С. 215-219.

11. Мурадов, С. В. Микробиологические свойства и биомедицинское тестирование пелоидных препаратов из активированной лечебной грязи / С. В. Мурадов // Вестник новых медицинских технологий. - 2013. - Т. 20, № 4. - С. 38.

12. Биологически активные медицинские препараты на основе сапропелевого гуминового комплекса / В. В. Платонов, М. А. Ларина, Е. Д. Дмитриева, М. А. Бодял // Вестник новых медицинских технологий. - 2016. - № 2, Публ. 1-1. doi: 10.12737/19646.

13. Струс, О. Є. Перспективи використання сапропелів у медицині та косметології / О. Є. Струс // Український журнал клінічної та лабораторної медицини. - 2014. - Т. 9, № 2. - С. 56-62. 
14. Фізор, Н. С. Вивчення цілющих властивостей вітчизняних лікувальних грязей і перспективи створення нових лікарських форм на їх основі / Н. С. Фізор, К. В. Тарасова // Актуальні питання фармацевтичної і медичної практики. - 2012. - № 3 (10). - С. 23-25.

15. Сметаніна, К. І. Основи стандартизації та сертифікації / К. І. Сметаніна. - Вінниця : Нова Книга, 2010. - $376 \mathrm{c}$.

16. Сметаніна, К. І. Рослинні ліки. Проблеми розробки лікарських засобів рослинного походження / К. І. Сметаніна // Фармацевтичний часопис. - 2011. - № 2. - С. 95-98.

17. Гумадапт - новый гуминовый препарат, регулятор обменных процессов и активный детоксикант [Электронный ресурс]. - Режим доступа: http://www.laboratorium.narod.ru/gumadapt. html (дата обращения: 01.07.2017).

18. Косметика Сакского озера [Электронный ресурс] // Сакское озеро: официальный сайт. - Режим доступа: http://sakilake.com (дата обращения: 12.02.2019).

19. Промислова технологія лікарських засобів : базовий підручник для студ. вищ. навч. фармац. закл. (фармац. ф-тів) / Є. В. Гладух [та ін.]. - Х. : НФаУ : Оригінал, 2016. - 632 с.

20. Струс, О. Є. Маркетингові дослідження лікарських та косметичних засобів на основі лікувальних грязей (пелоїдів) / 0. Є. Струс // Управління, економіка та забезпечення якості в фармації. - 2015. - № 1 (39). - С. 59-67.

21. Сравнительный анализ термодинамических характеристик гумусовых кислот пелоидов [Электронный ресурс] / Н. П. Аввакумова, С. Х. Шарипова, М. А. Кривопалова, А. В. Жданова, Е. Е. Катунина, М. Н. Глубокова, И. В. Фомин // Современные проблемы науки и образования. - 2017. - № 6. - Режим доступа: http://www.science-education.ru/ru/article/view?id=27214 (дата обращения: 12.02.2019).

22. Аввакумова, Н. П. Исследование антиоксидантных свойств гуминовых кислот пелоидов / Н. П. Аввакумова, М. Н. Глубокова, Е. Е. Катунина // Известия Самарского научного центра Российской академии наук. - 2013. - Т. 15, № 3 (3). - С. 1160-1162.

23. Рыжова, Г. Л. Определение жирных кислот в продуктах вибромагнитной переработки сапропеля методом хромато-масс-спектрометрии / Г. Л. Рыжова, М. А. Тюнина, К. А. Дычко // Журнал аналитической химии. - 2013. - Т. 68, № 8. - С. 808-814.

24. Биологическое действие сапропеля / В. В. Платонов, А. А. Хадарцев, С. Н. Чуносов, К. Я. Фридзон // Фундаментальные исследования. - 2014. - № 9-11. - С. 2474-2480.

25. Штин, С. М. Озерные сапропели и их комплексное освоение [Электронный ресурс] / С. М. Штин; ред. И. М. Ялтанец. - Москва : Московский государственный горный университет, 2005. - 374 с. - Режим доступа: http://biblioclub.ru/index.php?page=book\&id=79508 (дата обращения: 15.04.2019).

26. Державний реєстр лікарських засобів України [Електронний ресурс]. - Режим доступу: http:// www.drlz.com.ua/ (дата звернення: 12.02.2019).

27. Державний формуляр лікарських засобів 10 випуск. Xls [Електронний ресурс]. - Режим доступу: http://www.dec.gov.ua/index.php/ua/informatsijno-poshukova-sistema-elektronnij-formulyar (дата звернення: 12.02.2019).

28. Компендиум. Лекарственные средства. АТС-классификация [Электронный ресурс]. - Режим доступа: https://compendium.com.ua/use_atc/ (дата обращения: 12.02.2019).

29. Премиксы. Пищевые ингредиенты. Кормовые добавки [Электронный ресурс]. - Режим доступа: http://www.zaorespect.ru/index.php/premix.html (дата обращения: 26.06.2017).

30. Экстракт сапропеля (ЭС-2). Пищевые ингредиенты. Кормовые добавки [Электронный ресурс]. - Режим доступа: http://www.zaorespect.ru/index.php/sapropelextract.html (дата обращения: 26.06.2017).

31. Производство премиксов для КРС. Премикс-Милк [Электронный ресурс]. - Режим доступа: http://www.agropremix.ru/page4.html (дата обращения: 26.06.2017).

32. Премиксы-концентраты «Кладезь 34 рецепта» [Электронный ресурс]. - Режим доступа: http://www.agropremix.ru/page4.html (дата обращения: 26.06.2017).

33. Гумат натрия «Фрея» - кормовая добавка в Украине [Электронный ресурс]. - Режим доступа: http://freya-agro.com.ua/ru/production/gumat-natria-freya-kormovaja-dobavka (дата обращения: 04.07.2017).

34. Торф Сибири [Электронный ресурс]: официальный сайт проекта по созданию и развитию торфяного кластера в Томской области. - Режим доступа: http://tomsktorf.blogspot.com/p/ blog-page_20.html (дата обращения: 26.06.2017).

35. Гувитан-S [Электронный ресурс]. - Режим доступа: https://ru.wikipedia.org/wiki/\%D0\%93\%D 1\%83\%D0\%B2\%D0\%B8\%D1\%82\%D0\%B0\%D0\%BD-\%D0\%A1 (дата обращения: 26.06.2017). 


\section{References}

1. Dobavki kormovye: Sapropel dlia kormovykh dobavok. Available at: http://gskp.by/DetailProd.ph p?UrlReg=0\&UrlDist $=0 \&$ UrlGoodsId $=42525 \&$ UrlKlpId $=37984 \&$ UrlGoodsAssrId $=80714 \&$ TabId $=3$

2. Spisok zaregistrirovannykh kormovykh dobavok. Available at: https://galen.vetrf.ru/\#/registry/ feed/registry?page $=1$

3. Avvakumova, N. P., Krivopalova, M. A., Fomin, I. V., Zhdanova, A. V. (2010). Voprosy biologicheskoi, meditcinskoi i farmatcevticheskoi khimii, 11, 24-27.

4. Karagulov, Kh. G. (2016). Sozdanie i metodologiia lekarstvennykh i kosmetcevticheskikh sredstv, soderzhashchikh tambukanskie peloidy, na osnove sovremennykh resursosberegaiushchikh tekhnologii. Doctor's thesis. Piatigorsk, 320. Available at: http://www.dslib.net/klinika-farmakologia/ sozdanie-i-metodologija-lekarstvennyh-i-kosmecevticheskih-sredstv-soderzhawih.html

5. Ryzhova, G. L., Dychko, K. A., Khasanov, V. V., Bogachev, S. A., Kuriaeva, T. T. cyberleninka.ru. Available at: https://cyberleninka.ru/article/n/mehano-fizicheskaya-tehnologiya-pererabotki-prirodnogoorganicheskogo-syrya-i-poluchenie-produktov-funktsionalnogo-naznacheniya

6. Donni vidklady pryrodnykh vodoim Volynskoi oblasti ta perspektyvy yikh vykorystannia u rekreatsii. Available at: http://dspace.nbuv.gov.ua/bitstream/handle/123456789/35497/37-Kalinovskiy.pdf?sequence=1

7. Shevchuk, M. Y., Didkovska, T. P., Bortnik, A. M. (2009). Naukovyi visnyk Volynskoho natsionalnoho universytetu imeni Lesi Ukrainky. Heohrafichni nauky, 1, 83-85.

8. Khmelivskyi, V. O., Baranov, V. I., Kostiuk, O. V. (2011). Zapovidna sprava v Ukraini, 11 (1-2). Available at: http://aetos.kiev.ua/zsu/zsu17/zsu17-16.pdf

9. Polnyi katalog zaregistrirovannykh $v$ Ukraine veterinarnykh preparatov VET.in.UA. Available at: http:// vet.in.ua/menu/drugs.php

10. Karagulov, KH. G. (2015). Aktual\&apos;nye problemy gumanitarnykh i yestestvennykh nauk, 4 (2), 215-219.

11. Muradov, S. V. (2013). Vestnik novykh meditsinskikh tekhnologii, 20 (4), 38.

12. Platonov, V. V., Larina, M. A., Dmitrieva, Ye. D., Bodial, M. A. (2016). Vestnik novykh meditsinskikh tekhnologii, 2 (1-1). doi: 10.12737/19646.

13. Strus, O. Y. (2014). The prospects of sapropel use in medicine and cosmetology. Ukrainian Journal of Clinical and Laboratory Medicine, 9 (2), 56-62.

14. Fyzor, N. S., Tarasova, K. V. (2012). Aktualni pytannia farmatsevtychnoi i medychnoi praktyky, 3 (10), 23-25.

15. Smetanina, K. I. (2010). Osnovy standartyzatsii ta sertyfikatsii. Vinnytsia: Nova Knyha, 376.

16. Smetanina, K. I. (2011). Farmatsevtychnyi chasopys, 2, 95-98.

17. Gumadapt - novyi guminovyi preparat, reguliator obmennykh protsessov i aktivnyi detoksikant. Available at: http://www.laboratorium.narod.ru/gumadapt.html.

18. Kosmetika Sakskogo ozera. Sakskoye ozero: ofitsial\&apos;nyi sait. Available at: http://sakilake.com

19. Gladukh, Ye. V. et al. (2016). Promyslova tekhnolohiya likarskykh zasobiv. Kharkiv: NFaU: Oryginal, 632.

20. Strus, O. Ye. (2015). Upravlinnia, ekonomika ta zabezpechennia yakosti v farmatsii, 1 (39), 59-67.

21. Avvakumova, N. P., Sharipova, S. Kh., Krivopalova, M. A., Zhdanova, A. V., Katunina, Ye. Ye., Glubokova, M. N., Fomin, I. V. (2017). Sovremennye problemy nauki i obrazovaniia, 6. Available at: http://www. science-education.ru/ru/article/view?id=27214

22. Avvakumova, N. P., Glubokova, M. N., Katunina, Ye. Ye. (2013). Izvestiia Samarskogo nauchnogo tsentra Rossiiskoi akademii nauk, 15 (3 (3)), 1160-1162.

23. Ryzhova, G. L., Tiunina, M. A., Dychko, K. A. (2013). Zhurnal analiticheskoi khimii, 68 (8), 808-814.

24. Platonov, V. V., Khadartsev, A. A., Chunosov, S. N., Fridzon, K. Ya. (2014). Fundamental\&apos;nye issledovaniia, 9 (11), 2474-2480.

25. Shtin, S. M. (2005). Ozernye sapropeli i ikh kompleksnoe osvoenie. I. M. Yaltanets (Ed.). Moskow: Moskovskii gosudarstvennyi gornyi universitet, 374 . Available at: $\mathrm{http}$ ://biblioclub.ru/index.php?page=book\&id=79508

26. Derzhavnyi reiestr likarskykh zasobiv Ukrainy. Available at: http://www.drlz.com.ua/

27. Derzhavnyi formuliar likarskykh zasobiv 10 vypusk. Khls. Available at: http://www.dec.gov.ua/index. $\mathrm{php} / \mathrm{ua}$ /informatsijno-poshukova-sistema-elektronnij-formulyar

28. Kompendium. Lekarstvennye sredstva. ATS-klassifikatsiia. Available at: https://compendium.com.ua/ use_atc/

29. Premiksy. Pishchevye ingredienty. Kormovye dobavki. Available at: http://www.zaorespect.ru/index. $\mathrm{php} / \mathrm{premix} \cdot \mathrm{html}$

30. Ekstrakt sapropelya (ES-2). Pishchevyye ingrediyenty. Kormovyye dobavki. Available at: http://www. zaorespect.ru/index.php/sapropelextract.html

31. Premiks-Milk. Proizvodstvo premiksov dlya KRS. Available at: http://www.agropremix.ru/page4.html 
32. Premiksy-kontsentraty "Kladez\&apos; 34 retsepta". Available at: http://www.agropremix.ru/page4.html

33. Gumat natriia "Freia" - kormovaia dobavka v Ukraine. Available at: http://freya-agro.com.ua/ru/ production/gumat-natria-freya-kormovaja-dobavka

34. Torf Sibiri: ofitsial\&apos;nyi sait proekta po sozdaniiu i razvitiiu torfianogo klastera v Tomskoi oblasti. Available at: http://tomsktorf.blogspot.com/p/blog-page_20.html

35. Guvitan-S. Available at: https://ru.wikipedia.org/wiki/\%D0\%93\%D1\%83\%D0\%B2\%D0\%B8\%D1 $\% 82 \%$ D0\%B0\%D0\%BD-\%D0\%A1

Information about authors:

Strus $\boldsymbol{O}$. Y., Candidate of Pharmacy (Ph.D.), associate professor of the Department of Drug Technology and Biopharmaceutics, Danylo Halytsky Lviv National Medical University (https://orcid.org/0000-0003-1638-1162). E-mail: oxana.strus@ukr.net Polovko N. P., Doctor of Pharmacy (Dr.habil), professor of the Department of Drug Technology, National University of Pharmacy (https://orcid.org/0000-0003-3189-7394).E-mail: polovko.np@gmail.com

Smetanina K. I., Candidate of Pharmacy (Ph.D.), associate professor of the Department of Management and Economy of Pharmacy and Drug Technology of the Postgraduate Education Faculty, Danylo Halytsky Lviv National Medical University (https://orcid.org/0000-0003-0040-2096).E-mail: smetanina_k@ukr.net

Відомості про авторів:

Cmpyc O. $\boldsymbol{\epsilon}$, кандидат фармацевтичних наук, доцент кафедри технології ліків і біофармації, Львівський національний медичний університет імені Данила Галицького (https://orcid.org/0000-0003-1638-1162). E-mail: oxana.strus@ukr.net Половко Н. П., доктор фармацевтичних наук, професор кафедри технології ліків, Національний фармацевтичний університет (https://orcid.org/0000-0003-3189-7394). E-mail: polovko.np@gmail.com

Сметаніна К. I., кандидат фармацевтичних наук, доцент кафедри організації і економіки фармації, технології ліків та фармакоекономіки факультету післядипломної освіти, Львівський національний медичний університет імені Данила Галицького (https://orcid.org/0000-0003-0040-2096).E-mail: smetanina_k@ukr.net

Сведения об авторах:

Cmpyc O. E., кандидат фармацевтических наук, доцент кафедры технологии лекарств и биофармации, Львовский национальный медицинскй университет имени Данила Галицкого (https://orcid.org/0000-0003-1638-1162).

E-mail: oxana.strus@ukr.net

Половко Н. П., доктор фармацевтических наук, профессор кафедры технологии лекарств, Национальный фармацевтический университет (https://orcid.org/0000-0003-3189-7394). E-mail: polovko.np@gmail.com Cметанина E. И., кандидат фармацевтических наук, доцент кафедры организации и экономики фармации, технологии лекарств и фармакоэкономики факультета последипломного образования, Львовский национальный медицинскй университет имени Данила Галицкого (https://orcid.org/0000-0003-0040-2096). E-mail: smetanina_k@ukr.net 